\title{
VINCULAÇÕES ORÇAMENTÁRIAS NÃO SÃO A PANACEIA DOS PROBLEMAS
}

Coluna publicada em 8.4.2014: <http://www.conjur.com.br/2014-abr-08/ contas-vista-vinculacoes-orcamentarias-nao-sao-panaceia-problemas $>$

Há vinte anos, em $1^{\circ}$ de março de 1994, surgia o Fundo Social de Emergência, por meio da Emenda Constitucional de Revisão 1, de 1994, que o instituiu acrescentando os artigos 71 a 73 no Ato das Disposições Constitucionais Transitórias. Precursor da Desvinculação de Receitas da União (DRU), prevista na Emenda Constitucional 27, de 2000, ambos tratam da polêmica questão orçamentária das vinculações de receitas. Uma boa oportunidade para trazer o tema para debate.

Vê-se o tempo todo, e não é de hoje, notícias sobre soluções para inúmeros problemas baseadas nas "vinculações". Vinculaçôes de todo o tipo. Vincular recursos para a saúde, educação, moradia e tantas outras políticas públicas. Soam como se vincular receitas para determinadas finalidades fosse a solução milagrosa para todos os problemas da área.

Curioso e interessante notar como as vinculações atraem o interesse dos legisladores, que, agindo com boa-fé e as melhores intenções, têm enorme apreço por criar leis "vinculando" receitas para finalidades que têm apelo popular e interesse público, como se assim fazendo estivessem, num passe de mágica, resolvendo todos os problemas. Tanto exageraram nisso que esse ânimo só pode ser contido por meio de norma constitucional, hoje erigida ao status de princípio orçamentário - o "princípio da não afetação", ou, para parte dos autores, "princípio da não vinculação", que em nosso ordenamento jurídico vem contemplado no artigo 167, IV, da Constituição.

Se assim não fosse, seguramente nossos chefes de Poder Executivo dos vários entes da federação e administradores públicos em geral pouca ou nenhuma discricionariedade teriam na gestão das finanças públicas, uma vez que todos os recursos estariam previamente destinados a algum gasto. Administrar resumir-se-ia a contemplar o fluxo dos recursos "carimbados", sem que fosse possível nele interferir. 
Mesmo submetida à forte limitação constitucional, as vinculações continuam a existir e aumentar, tanto que motivaram a edição das emendas constitucionais mencionadas no início desta coluna, estabelecendo "desvinculações" gerais, permitindo uma maior discricionariedade na alocação dos recursos no orçamento público.

Esquecem-se os legisladores, administradores e a sociedade de modo geral que as vinculações, por si só, pouco representam em termos de melhoria da qualidade do gasto público. Sei que palavras como essas soam como um "balde de água fria" nos esperançosos legisladores e mesmo na sociedade em geral, que vê nelas uma verdadeira "luz no fim do túnel" para inúmeras deficiências na atenção ao cumprimento de direitos fundamentais do ser humano que ao Estado cabe prover. Mas é a dura realidade.

Cumpre observar que os orçamentos públicos, quaisquer que sejam eles - da União, estados ou municípios -, contemplam muito dinheiro. Só para que se tenha uma ideia, o da União compreende valores na ordem de 2,5 trilhões de reais; o do Estado de São Paulo, próximo de 190 bilhões, e o do Município de São Paulo, 50 bilhões. Muitos desses recursos estão de alguma forma "vinculados", quer seja por vinculaçōes propriamente ditas, quer seja por estarem destinados a despesas obrigatórias - outra figura orçamentária de engessamento dos gastos públicos - e, portanto com pouca margem de discricionariedade na decisão sobre a alocação do gasto.

Apenas para ilustrar o leitor, embora seja questão técnica, convém abrir parênteses para esclarecer haver certa confusão no uso do termo "vinculação", inclusive por parte do legislador. O termo "vinculação" é apropriado para referir-se às hipóteses em que se estabelece uma ligação entre receitas e despesas específicas, um "elo normativo entre uma fonte e um destino", como é o caso, por exemplo, da "CIDE-combustíveis" para o financiamento da infraestrutura de transportes (CF, art. $\left.177, \$ 4^{\mathrm{o}}, \mathrm{II}, c\right)$. Outra coisa são os gastos ou despesas mínimas obrigatórias, em que há determinação constitucional ou legal para compelir o administrador a aplicar um mínimo de recursos públicos, arrecadados em um determinado exercício, para certa finalidade. É o que ocorre, por exemplo, na educação, em que a Constituição, no seu artigo 212, prevê que caberá à União aplicar anualmente, "nunca menos de dezoito, e os Estados, o Distrito Federal e os Municípios vinte e cinco por cento, no mínimo, da receita resultante de impostos [...] na manutenção e desenvolvimento do ensino". ${ }^{1}$ Registro, ainda, o uso impróprio da expressão em nossa

Sobre o tema, recomendo a leitura da obra Vinculação de receitas públicas, de André Castro Carvalho, que tratou com muita propriedade do tema (São Paulo: Quartier Latin, 2010). 
Constituição, ao chamar de vinculação as repartições de receitas tributárias utilizadas no nosso sistema de federalismo fiscal, como se vê no artigo 167, IV.

Mesmo assim, a margem de "manobra" dessa enorme quantidade de recursos orçamentários, pelas várias possibilidades existentes no âmbito da administração pública, por técnicas administrativas, contábeis, jurídicas e de outra natureza ainda é grande. Soluções simples permitem contornar com relativa facilidade as vinculações. Veja-se, por exemplo, uma criação de contribuição com recursos vinculados à área da saúde, como ocorreu por certo período com a CPMF. Criar um tributo novo, com recursos destinados à saúde, importa em um significativo aumento da destinação de recursos para a saúde, não é mesmo? Não necessariamente. Os recursos até então destinados à saúde não eram em boa parte "vinculados", de modo que, em tese, nada impede de, havendo recursos agora exclusivos para a área da saúde, os que lhe eram anteriormente alocados deixem de sê-lo, voltem-se para despesas em outras áreas, ficando a saúde agora financiada pelos recursos vinculados da referida contribuição. A "vinculação" criada foi importante instrumento para assegurar arrecadação de dinheiro para a saúde, mas efetivamente pode não representar acréscimo de um único centavo ao setor.

Mesmo a vinculação para uma determinada área não é simples de se operacionalizar. Muitos são os recursos com destinação específica para a educação, obrigando o administrador a gastá-los apenas e tão somente nessa área. Mas o que é exata e precisamente educação e quais gastos podem ser considerados inerentes a ela? Não há dúvidas quanto ao salário dos professores e aos gastos com material escolar. Mas há muitas outras despesas que permitem extensas discussōes, muitas delas já objeto de debates e decisões, tanto no âmbito acadêmico quanto em órgãos que tratam do tema, como os Tribunais de Contas, ou mesmo no próprio Poder Judiciário. É o caso, por exemplo, apenas para citar alguns, do pagamento de salários de aposentados e pensionistas, da merenda escolar, campanhas educativas, enfim, há uma extensa gama de possibilidades que permitem tornar por demais elástico o que pode e o que não pode ser considerado gasto com educação. E assim o é em outras áreas: saúde, segurança, justiça, entre outros.

E nem discorrerei sobre a comprovada ineficácia de vinculaçóes ou aumento nas receitas como medida que melhore, por si só, determinado setor ou política pública. As recentes propostas de vinculações de recursos para a educação, quer pela destinação de recursos dos royalties do petróleo, quer pela "vinculação" de $10 \%$ do PIB, esbarram na constatação de que o Brasil já gasta com educação valores proporcionalmente equivalentes aos países desenvolvidos, como já mencionei em coluna anterior, sem que isso tenha resultado em efetiva melhora na prestação 
do serviço. ${ }^{2}$ Melhorias na gestão produzem mais efeito do que aumento nos gastos, como já disse tempos atrás. ${ }^{3}$

O que se vê é uma verdadeira "guerra" entre o Poder Executivo e o Legislativo, este querendo vincular, e aquele, desvincular recursos. Uma disputa de poder na arena do orçamento público.

As vinculações são apenas instrumentos dessa guerra. Instrumentos que podem ser úteis para nos proteger dos maus governantes, obrigando-os a aplicar recursos nas áreas mais importantes; mas prejudicam os bons governantes, tirando- lhes a discricionariedade para usar o dinheiro público da forma que pode se mostrar mais adequada ao interesse da coletividade. As vinculações, tal como as facas, não são boas ou más. Bom ou ruim é o uso que se faz delas. Tanto podem ser úteis para salvar vidas, como fazem os médicos com seus bisturis, como para acabar com elas, como fazem os assassinos.

Uma guerra cujo foco está de todo equivocado, pois a questão principal não é para onde destinar os recursos, mas sim como utilizá-los bem.

2 Nem só com royalties se melhora a qualidade da educação, publicada em 30 de julho de 2013.

3 Veja-se a coluna Não falta dinheiro à administração pública, falta gestão, publicada em 31 de julho de 2012. 